\title{
Pelatihan Komposisi untuk Peningkatan Desain Motif Bahan dan Desain Fashion bagi Pengrajin Shibori dan Ecoprint
}

\author{
Christian Nindyaputra Octarino ${ }^{1}$, Patricia Pahlevi Noviandri ${ }^{2}$ \\ Universitas Kristen Duta Wacana \\ 1 christian.octarino@staff.ukdw.ac.id \\ 2 patriciapahlevi@staff.ukdw.ac.id
}

\begin{abstract}
For most people, fashion and lifestyle are two things that cannot be separated. Dressing is not just to cover the body, but it can symbolize someone's personality and identity. Therefore, fashion manufacturers competing to bring innovations to their products so that they can attract more people. One of the innovations in the field of fashion is ecoprint and shibori, which emphasizes the use of natural dyes in the manufacturing process. With the phenomenon of environmental pollution, this technique becomes more popular because it promises an environmentally friendly on its process. Not only from processing techniques, innovation also needs to be done on the design of the product. Design remains one of the main considerations of consumers in buying a product, including fashion products. This study was conducted during the Workshop of Design Composition for motif and fashion Improvement, initiated by Faculty of Architecture and Design UKDW collaborated with Paroki Keluarga Kudus Banteng dan PEJ GKJ Pakem Yogyakarta. This workshop focuses on the creativity of artisans in finding interesting compositions used in shibori and ecoprint techniques. Furthermore, the workshop method will also be used to find designs for fashion products that are attractive and suitable for the market in the present. The purpose of this study was to determine the effectiveness of the workshop method used for the responses and achievements of the participants.
\end{abstract}

Keywords: workshop, design, composition, creative, fashion.

\section{PENDAHULUAN}

Busana/sandang merupakan salah satu dari tiga kebutuhan pokok manusia sehingga akan selalu dibutuhkan sampai kapanpun juga. Seiring dengan perkembangan jaman, busana tidak hanya menjadi sekedar kebutuhan pokok namun sudah berkembang menjadi lambang identitas dari seseorang. Hendraningrum dan Susilo (2014) menyatakan bahwa benda-benda seperti baju dan aksesoris sudah bukan hanya berfungsi sebagai sekedar penutup tubuh, namun sebagai media untuk mengkomunikasikan identitas pribadi [1]. Di era globalisasi ini, lifestyle atau gaya hidup telah menjadi salah satu aspek yang sangat diperhatikan oleh manusia dalam kehidupan sehari-hari. Hal ini direspon oleh para produsen bidang fashion untuk terus mengembangkan kreasi dan inovasi produknya agar dapat memiliki nilai jual yang tinggi. Menurut Hartini (2012), inovasi merupakan salah satu faktor utama dalam menghadapi persaingan industri. Inovasi dapat berupa inovasi produk maupun inovasi proses [2]. Inovasi produk menekankan pada produk yang benar-benar baru, sedangkan inovasi proses lebih menekankan pada bagaimana manajemen dalam produksi suatu produk yang dapat meningkatkan kualitas namun mengurangi dampak negatif yang ada.

Sustainabilitas saat ini menjadi isu utama di tengah menurunnya kualitas lingkungan hidup manusia. Hal ini ikut mempengaruhi tren dalam industri fashion yang beredar di masyarakat. Industri tekstil dianggap menjadi salah satu sumber pencemaran lingkungan, terutama zat-zat pewarna yang berasal dari bahan-bahan 
kimia. Zat pewarna tekstil akan menghasilkan limbah cair yang nantinya akan dialirkan melalui sungai. Hal ini akan menyebabkan pencemaran sungai yang berdampak pada menurunnya kualitas air, dan juga mengganggu kehidupan organisme yang hidup di dalamnya (Pratiwi, 2010) [3]. Merespon fenomena tersebut, mulai bermunculan berbagai macam teknik pengolahan dan juga pewarnaan tekstil, diantaranya adalah teknik ecoprint yang menggunakan bahan pewarna alami. Menurut Enrico (2019), teknik ecoprint telah menjadi salah satu alternatif inovasi dalam industri tekstil yang dapat mengurangi limbah cair serta dapat meningkatkan kualtias dan nilai jual produk [4]. Inovasi lain yang juga tengah populer adalah teknik shibori, yaitu teknik yang mengacu pada proses pembentukan motif yang dihasilkan dari ikatan, lipatan, jelujuran, dan serutan yang kemudian dicelupkan ke dalam larutan pewarna [5]. Motif yang terbentuk akan mengikuti pola dari lipatan yang ada sebelumnya. Selain pembentukan motif, teknik yang berasal dari Jepang ini juga menekankan pada penggunaan bahan pewarna alami, yang lebih ramah lingkungan. Tidak hanya pada kain, shibori juga dapat diaplikasikan pada beragam produk fashion lain, seperti tas, syal, bahkan juga sepatu. Southan (2008) menyatakan bahwa kombinasi dari teknik kuno dan inovasi material dan produk menjadikan shibori salah satu produk tekstil bergaya kontemporer yang menarik [6]

Selain inovasi pada teknik dan proses olahan, yang terpenting pada sebuah produk fashion adalah desain dari produk itu sendiri. Desain tetap menjadi salah satu pertimbangan utama konsumen dalam memilih sebuah produk. Apapun teknik dan proses yang digunakan, pada akhirnya konsumen akan tetap melihat kualitas desain yang ada, termasuk pada produk tekstil/fashion. Kelompok pengrajin dari Paroki Gereja Keluarga Kudus Banteng maupun PEJ Gereja Kristen Jawa Pakem yang sebelumnya telah mendapatkan pelatihan mengenai ecoprint serta shibori sudah memiliki pemahaman mengenai apa keunggulan dari teknik tersebut dan bagaimana mengimplementasikan pada media tekstil dengan menggunakan pewarna alami. Mengingat aspek desain juga merupakan pertimbangan utama konsumen, maka tim pengabdian UKDW menilai perlu adanya pelatihan lanjutan yang spesifik pada pemahaman mengenai desain bagi para anggota kelompok pengrajin. Jika dilihat dari latar belakang anggota pengrajin, sebagian besar masih awam tentang desain, sehingga perlu diberikan prinsip-prinsip dasar dalam desain sehingga nantinya akan dapat mengembangkannya menjadi desain motif untuk kain. Setiap hasil karya pada bisnis kreatif khususnya bisnis fashion perlu memiliki nilai keindahan atau nilai seni. Suatu karya desain memiliki nilai seni apabila terdapat tujuh prinsip dasar komposisi dalam desain. Tujuh prinsip dasar desain adalah Irama, Kesatuan, Dominasi, Keseimbangan, Proporsi, Kesederhanaan, dan Kejelasan. Tujuan dari workshop ini adalah untuk meningkatkan proses kreatif dari masing-masing anggota kelompok pengrajin shibori Paroki Keluarga Kudus Banteng dan PEJ GKJ Pakem. Karya yang dihasilkan melalui proses kreatif diharapkan akan memiliki nilai jual yang lebih sehingga akan meningkatkan perekonomian bagi masingmasing anggota kelompok. Pelatihan akan lebih ditekankan pada workshop/praktik, yang dinilai akan lebih memberikan keleluasaan bagi para peserta untuk dapat mengeksplorasi kreativitas masing-masing. Penyusunan metode pelatihan didasarkan pada alur proses desain menurut Royal Institute of British Architects [7]:

1. Asimilasi, akumulasi dan pengaturan informasi umum dan informasi khusus berkaitan dengan masalah

2. Studi umum, investigasi karakterisik permasalahan dan solusi yang mungkin ada atau alat solusi 
3. Pengembangan dan modifikasi satu solusi tentatif atau lebih yang diisolasi selama tahap studi umum

4. Komunikasi, mengkomunikasikan satu solusi atau lebih pada orang di dalam atau luar tim desain

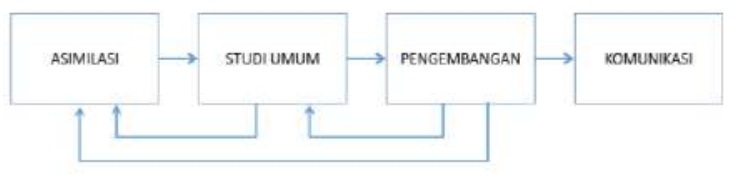

Gambar 1. Peta proses desain Royal Institute of British Architects

(Bryan Lawson, 2012)

\section{METODE PELAKSANAAN}

Penelitian pada kegiatan pengabdian ini dilakukan dengan metode deskriptif kualitatif. Eksplorasi dilakukan pada teori serta prinsip-prinsip dalam merancang komposisi desain, yang dijadikan sebagai dasar pengamatan pada setting kegiatan Workshop Pelatihan Komposisi untuk peningkatan motif bahan dan desain fashion. Pengamatan dilakukan selama kegiatan berlangsung, dengan aspek amatan adalah sebagai berikut:

- Proses interaksi antara narasumber dan peserta pelatihan pada tahap penyampaian materi

- Proses workshop pembuatan komposisi desain untuk motif yang merupakan kelanjutan dari materi yang telah diberikan

Pengamatan dilakukan dengan perekaman digital (foto dan video) dan juga melalui komunikasi langsung dengan para peserta workshop, narasumber, dan pihak-pihak lain yang turut terlibat pada kegiatan ini.

Pelaku dalam kegiatan ini antara lain fasilitator dari Fakultas Arsitektur dan Desain UKDW, narasumber yang berpengalaman di bidang desain dan fashion, serta para peserta berjumlah 50 orang yang terdiri dari 2 kelompok pengrajin shibori dan ecoprint, masingmasing merupakan Warga Paroki Gereja
Keluarga Kudus Banteng dan Kelompok Pengembangan Ekonomi Jemaat Gereja Kristen Jawa Pakem (PEJ GKJ Pakem).

\section{HASIL KEGIATAN}

Kegiatan "Pelatihan Komposisi" ini diadakan dengan melibatkan peran serta dari Fakultas Arsitektur dan Desain UKDW bersama dengan Paroki Gereja Keluarga Kudus Banteng dan juga Kelompok PEJ GKJ Pakem. Kegiatan workshop ini dilaksanakan pada hari Sabtu, 11 Mei 2019 bertempat di Panti Paroki Gereja Keluarga Kudus Banteng Yogyakarta.

Sasaran dari kegiatan ini adalah warga dari Paroki Gereja Keluarga Kudus Banteng dan GKJ Pakem yang tergabung dalam kelompok pengrajin shibori dan ecoprint. Mereka yang tergabung dalam kelompok ini sebagian besar telah mendapatkan pelatihan mengenai teknik shibori dan ecoprint yang sebelumnya juga diinisiasi oleh Fakultas Arsitektur dan Desain UKDW. Bertindak sebagai fasilitator adalah tim dari FAD UKDW yang terdiri dari 6 dosen $(3$ dosen arsitektur dan 3 dosen desain produk), dan dibantu oleh 10 mahasiswa yang juga merupakan gabungan dari mahasiswa prodi arsitektur dan desain produk.

Gagasan mengenai kegiatan workshop ini didasari oleh pemikiran bagaimana sebuah desain dapat meningkatkan value sebuah produk, termasuk di dalamnya produk fashion. Para peserta yang sebelumnya sudah mendapatkan pelatihan mengenai teknik shibori dan ecoprint, dirasa masih perlu meningkatkan pemahaman mengenai prinsip-prinsip dasar menciptakan komposisi desain. Hasil yang diharapkan bahwa masing-masing peserta dapat mengembangkan ide desainnya sendiri di masa depan sehingga dapat meningkatkan daya jual dari produk yang dihasilkan. 


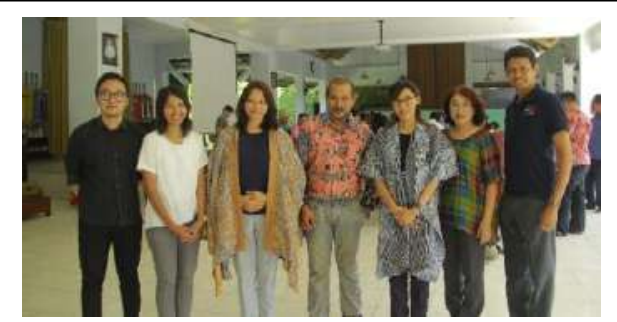

Gambar 2. Tim Fasilitator dari Fakultas Arsitektur dan Desain UKDW beserta narasumber

Kegiatan pelatihan komposisi secara garis besar terbagi menjadi 2 sesi, yaitu pemaparan materi pengantar dari narasumber mengenai prinsip-prinsip komposisi dalam desain, khususnya desain motif untuk kain. Materi dibawakan oleh Ibu Tutun Seliari, S.T., M.Sc. selaku dosen program studi arsitektur UKDW sekaligus pemilik dari Clekunik (pengrajin shibori dan ecoprint). Materi yang disampaikan memberi gambaran kepada peserta mengenai elemen-elemen apa saja yang akan berpengaruh pada komposisi dalam sebuah desain. Terdapat enam elemen yang berpengaruh pada komposisi desain, yaitu gambar, arah, warna, bentuk, ukuran, dan tekstur. Para peserta diberikan beberapa ilustrasi mengenai keberadaan elemenelemen tersebut di dalam sebuah desain motif. Sangat penting bagi para pengrajin untuk mengenali dan memahami elemenelemen desain ini agar mampu mengembangkan serta mengangkat nilainilai yang ada menjadi gagasan yang kreatif untuk diimplementasikan pada karya dua dimensi maupun tiga dimensi [8].

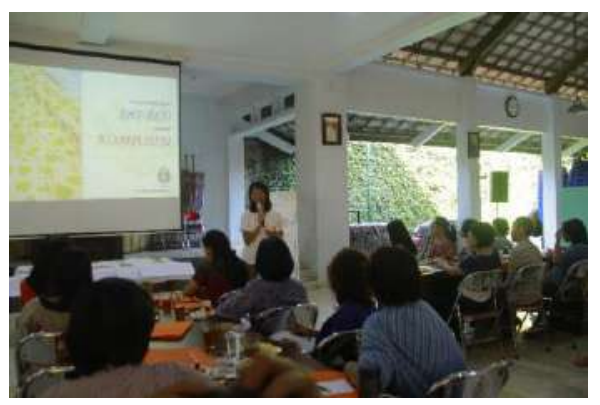

Gambar 3. Paparan Materi pengantar dari narasumber

Setelah memahami elemen-elemen pembentuk desain, kemudian diberikan pemahaman mengenai prinsip-prinsip komposisi yang dapat diterapkan pada motif kain. Prinsip tersebut diantaranya: [9]

\section{Irama (rhythm)}

Irama berarti gerak yang berulang atau mengalir secara konsisten, teratur, dan terus menerus. Irama dapat dibedakan menjadi repetisi (pengulangan dengan kesamaan), transisi (pengulangan dengan perubahan) maupun oposisi (pengulangan dengan perbedaan pada satu / beberapa unsur secara ekstrem)

\section{Kesatuan (unity)}

Kesatuan dapat dicapai dengan adanya kerapatan dan juga keterhubungan antar elemen. Prinsip kesatuan adalah adanya saling hubungan antar unsur yang disusun sehingga tidak ada bagian-bagian yang saling mengganggu, dan tidak dapat dipisahkan.

3. Penekanan (emphasis)

Penekanan merupakan salah satu prinsip dasar tata rupa yang harus ada pada karya desain agar memiliki nilai seni. Penekanan digunakan sebagai daya tarik. ada keunikan keganjilan yang menjadi dominan \& merebut perhatian (anomaly). Dapat disebut juga dengan point of interest, focal point, dan eye catcher.

4. Keseimbangan (balance)

Terjadi keseimbangan antar elemen (bisa berupa pola simetris maupun asimetris).

Para peserta juga dibekali mengenai pemilihan warna agar terlihat menarik. Penggabungan warna dilakukan agar motif dan desain pakaian dapat dilihat lebih menarik. Harmoni warna terdiri dari dua hal yaitu warna selaras dan warna kontras. Rahayu (2012) menyatakan bahwa warna dapat menyampaikan banyak hal pada orang yang mengalaminya, serta dapat menyampaikan sebuah maksud yang diinginkan seorang perancang pada karyanya [10]. Maka dari itu dalam sebuah produk fashion pun warna yang terdapat 
pada motif akan memiliki peran penting dalam menyampaikan maksud dari perancang tersebut.
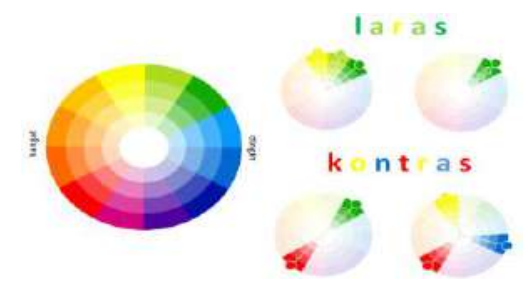

Gambar 4. Harmoni Warna

\section{Workshop Komposisi pada Desain Motif Bahan}

Menindaklanjuti materi yang telah diberikan, para peserta melakukan workshop komposisi pola pada kain. Media yang digunakan adalah kertas manila sebagai pengganti kain. Kertas manila yang digunakan ada dua macam, masing-masing mewakili kain syal dan juga kain panjang/meteran. Workshop dilakukan secara berkelompok, di mana masing-masing kelompok diminta membuat pola sesuai dengan prinsipprinsip komposisi yang telah dipahami sebelumnya. Pola komposisi dibuat dengan menggunakan daun dengan berbagai macam jenis dan ukuran, seolah menciptakan pola desain untuk ecoprint.

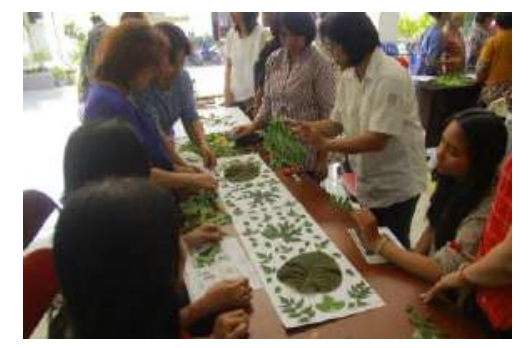

Gambar 5. Sesi Worskhop Komposisi pola pada kain

Hal utama yang perlu dilakukan terlebih dahulu oleh peserta adalah memahami karakteristik dari daun yang akan digunakan sebagai pola baik dari segi warna, ukuran, bentuk, dan teksturnya. Keragaman karakter daun ini yang dapat dimanfaatkan para peserta untuk menciptakan komposisi yang diinginkan.
Menurut para peserta, sesi pertama dalam pembuatan komposisi di sebuah kain ini sulit ketika membuat motif pada lembar kain. Peserta kesulitan dalam menata sesuai ketentuan yang diminta khususnya pada kelompok Irama dan Kesatuan. Prinsip Irama terlihat sangat mudah tetapi dalam prakteknya apabila terlalu sederhana, motif akan terlihat monoton dan membosankan. Sedangkan prinsip komposisi Kesatuan bagi mereka sulit mendapatkan komposisi ini karena belum memahami makna dari prinsip kesatuan itu sendiri. Pada dasarnya prinsip kesatuan adalah prinsip desain yang membuat satu sebuah motif dan tidak dapat dipisahkan / dipotong.

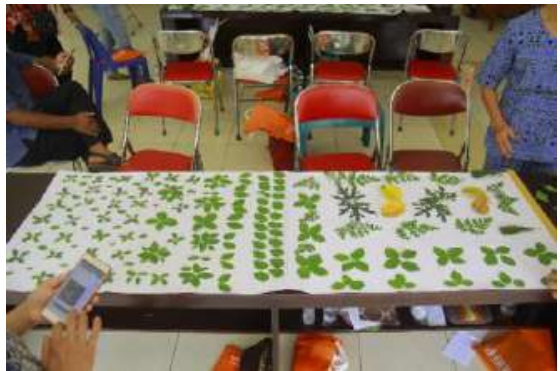

Gambar 6. Salah satu hasil Worskhop Komposisi pola pada kain

Pada sesi ini, peserta diharapkan membuat pola motif kain dengan memperhitungkan bagaimana cara kain ini diolah menjadi sebuah pakaian. Oleh sebab itu peletakkan polanya harus memungkinkan untuk penjahit mudah memotong dan menjahit kembali tanpa merusak polanya. Nilai dari sebuah produk kain bagi konsumen yaitu keindahan motif kain masih terlihat meskipun sudah dijadikan sebuah pakaian jadi. Ini menjadi tantangan bagi para pengrajin Ecoprint dan Shibori di workshop ini. Kain yang terlalu monoton maka tidak akan laku dengan mudah. Namun, apabila membuat kain dengan motif yang memiliki nuansa / cerita / harmonisasi maka akan memiliki daya tarik.

Pada workshop sesi pertama ini terlihat seluruh peserta tampak antusias dalam menyusun pola kain dari daun, dan aktif berkonsultasi dengan narasumber maupun fasilitator selama proses 
pengerjaan. Melalui workshop sesi pertama ini peserta dapat menguasai prinsip komposisi sehingga mampu menghasilkan desain motif kain yang memiliki daya tarik.

\section{Workshop Komposisi pada Desain Fashion}

Sesi kedua masih dalam rangkaian workshop komposisi pola motif tetapi lebih spesifik diperuntukkan untuk desain pakaian. Bahan yang digunakan untuk workshop ini adalah sebuah mal (cetakan) yang dibuat menyerupai bentuk sebuah pakaian, kemudian beberapa kertas yang sudah dicetak dengan motif Shibori dan Ecoprint. Tujuan dari workshop ini adalah peserta dapat menemukan padanan terbaik dari beberapa motif Shibori dan Ecoprint untuk desain pakaian.

Kegiatan ini masih dilakukan secara berkelompok, di mana masingmasing kelompok diminta membuat 3 desain terbaik dari motif-motif yang ada. Proses terpenting pada sesi ini adalah trial and eror, yaitu percobaan memadukan beberapa motif berulang kali sampai menemukan komposisi yang tepat. Metode ini direspon peserta dengan antusiasme tinggi. Dalam kegiatan ini terlihat dari banyaknya alternatif desain yang dihasilkan oleh masing-masing kelompok.

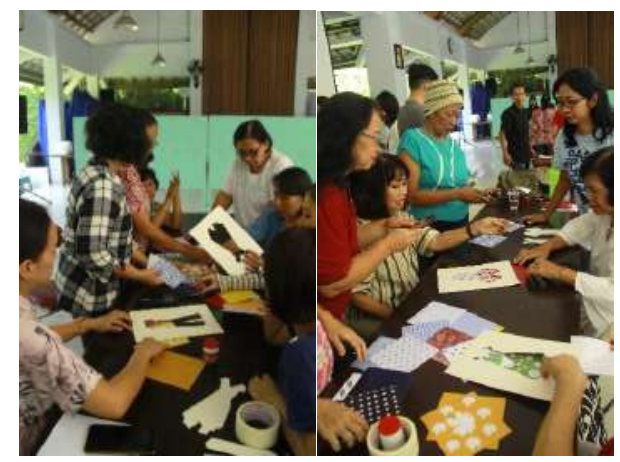

Gambar 7. Sesi Workshop Komposisi pada desain pakaian

Secara umum, kegiatan Pelatihan Komposisi untuk peningkatan desain motif bahan dan desain fashion bagi pengrajin Shibori dan Ecoprint dapat dikatakan berjalan dengan baik. Hal ini dapat dilihat pada antusiasme para peserta dalam mengikuti setiap sesi, dan juga hasil yang dicapai sesuai dengan yang diharapkan. Beberapa kendala yang ditemukan selama kegiatan berlangsung diantaranya adalah:

1. Jumlah peserta yang banyak menyebabkan komunikasi dengan narasumber cukup sulit, terutama saat berdiskusi

2. Jumlah anggota kelompok kerja dinilai masih terlalu banyak (10 orang tiap kelompok), sehingga saat proses brainstorming desain terjadi diskusi yang panjang/cukup lama untuk mengambil keputusan soal desain mana yang akan dipilih

3. Ketersediaan media untuk workshop yang terbatas, terutama untuk workshop kedua (pola desain pada desain pakaian). Hal ini menyebabkan peserta terbatas dalam membuat alternatif desain

Pada workshop ini, peserta lebih banyak melakukan kombinasi motif kain melalui harmoni warna. Kombinasi warna selaras dan kontras banyak dilakukan oleh para peserta. Setelah para peserta memilih warna terlebih dahulu selanjutnya mereka memperhatikan motif pada kain menggunakan prinsip komposisi yang telah diajarkan. Selain pemilihan kain, desain pakaian pun menggunakan prinsip komposisi seperti yang terlihat pada gambar 8 .

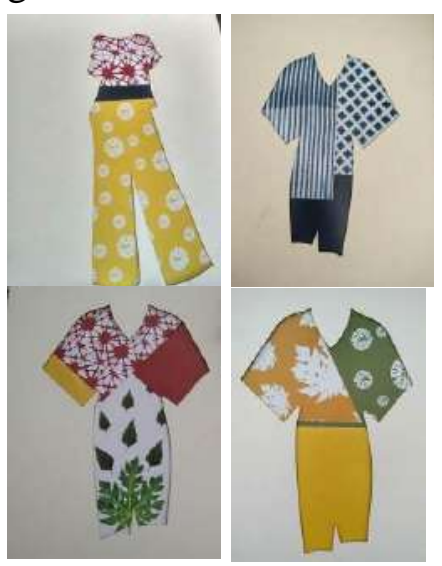

Gambar 8. Hasil dari Workshop Komposisi pada Desain Fashion 
Dikaitkan dengan alur proses desain, rangkaian kegiatan workshop telah memenuhi tahap-tahap yang perlu dijalani. Pada tahap awal yaitu asimilasi, merupakan sesi di mana peserta menerima materi dari narasumber yang menjadi bekal informasi dalam memahami permasalahan desain. Pada tahap ini, peserta diminta untuk mengkaitkan antara materi yang ada dengan pengalaman empiris mereka saat membuat sebuah karya kain dan karya fashion. Bagian ini menekankan bahwa kreativitas menjadi suatu tolak ukur keberhasilan bisnis Shibori dan Ecoprint. Peserta akan memahami pentingnya aspek kreativitas desain melalui prinsip komposisi sederhana mampu merubah sebuah hasil karya yang menarik.

Tahap selanjutnya adalah studi umum, yaitu tahap dimana para peserta mengidentifikasi dan memahami karakter dari media yang digunakan. Dalam kasus ini, media yang digunakan adalah dedaunan dan karton manila (untuk workshop pertama), kemudian kertas motif dan cetakan pakaian (untuk workshop 2). Fasilitator menjelaskan mengenai media yang akan digunakan dalam proses eksplorasi desain. Peserta harus memahami penggunaan dan kegunaan dari media yang telah disiapkan agar proses eksplorasi desain dapat memberikan berbagai macam alternatif desain.

Tahap yang terpenting adalah pada tahap ketiga yaitu peserta mengeksplorasi desain sesuai modul dan juga media yang dimiliki untuk dapat menghasilkan solusi berupa beberapa alternatif desain. Tahap ini juga berjalan beriringan dengan komunikasi, yang berarti terjadi komunikasi antar anggota kelompok dalam mengambil keputusan desain, juga komunikasi dengan narasumber untuk mendapatkan feedback mengenai desain yang telah dibuat.

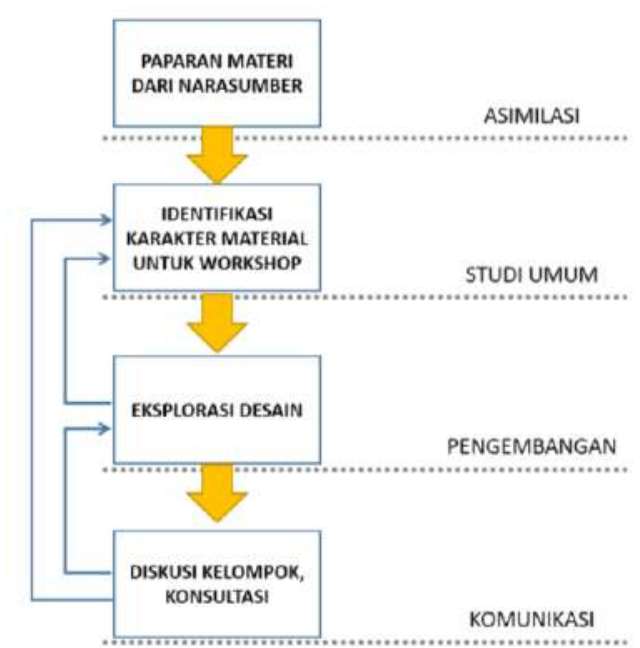

Gambar 9. Kesesuaian Metode Workshop dengan alur Proses dalam Desain

Metode dalam pelaksanaan kegiatan pengabdian ini dinilai efektif baik dari segi SDM maupun alat bantu. Hal ini dapat dilihat dari jumlah fasilitator yang dapat menangani jumlah peserta sebanyak 50 orang. Dengan adanya fasilitator di setiap kelompok mempermudah peserta untuk diskusi mengenai desainnya. Penggunaan alat yang mudah dilepas dan dirubah mampu membuat peserta mencoba berbagai macam pola yang memperlihatkan komposisi yang menarik. Dari metode tersebut, peserta juga diminta untuk memutuskan mana yang akan dipresentasikan sebagai bagian dari sebuah hasil.

\section{KESIMPULAN}

Kualitas desain tidak dapat dipisahkan dari nilai suatu produk, terkhusus produk-produk fashion. Kegiatan pelatihan dan workshop ini secara umum telah berhasil mengenalkan kepada para anggota pengrajin mengenai prinsipprinsip yang perlu diperhatikan dalam menciptakan desain untuk motif kain. Kualitas desain tidak dapat secara langsung meningkat. Dalam peningkatan desain diperlukan proses dan pengalaman untuk dapat memiliki kepekaan terhadap seni dan desain. Teknik ecoprint dan shibori yang telah dikuasai sebelumnya, hanya perlu dilengkapi dengan kreativitas desain 
produknya, terkhusus desain motif. Perlu ketekunan dari para pengrajin untuk dapat mencapai hasil yang optimal demi meningkatkan kualitas dan nilai jual produk yang akan dihasilkan.

\section{UCAPAN TERIMA KASIH}

Terimakasih kami sampaikan pada Lembaga Penelitian dan Pengabdian Masyarakat (LPPM) UKDW dan Fakultas Arsitektur dan Desain UKDW yang telah mendukung melalui dana untuk kegiatan ini. Kami juga berterimakasih kepada Paroki Gereja Keluarga Kudus Banteng dan juga PEJ GKJ Pakem atas kerjasamanya dalam penyelenggaraan kegiatan ini. Terimakasih pada mahasiswa volunteer dari program studi Arsitektur dan Desain Produk untuk kegiatan Pengabdian Masyarakat "Pelatihan Komposisi".

\section{DAFTAR PUSTAKA}

[1] R. Hendraningrum and M. E. Susilo, "Fashion dan Gaya Hidup: Identitas dan Komunikasi," Jurnal Ilmu Komunikasi, vol. 6, no. 1, 2014.

[2] S. Hartini, "Peran Inovasi: Pengembangan Kualitas Produk dan Kinerja Bisnis," Jurnal Manajemen dan Kewirausahaan, vol. 14, no. 1, pp. 82-88, 2012.

[3] Y. Pratiwi, "Penentuan Tingkat Pencemaran Limbah Industri Tekstil Berdasarkan Nutrition Value Coeficient Bioindikator," Jurnal Teknologi, vol. 3, no. 2, pp. 129-137, 2010.

[4] Enrico, "Dampak Limbah Cair Industri Tekstil terhadap Lingkungan dan Aplikasi Teknik Eco Printing sebagai Usaha Mengurangi Limbah," Jurnal MODA, vol. 1, no. 1, pp. 5-13, 2019.
[5] T. Yusrina and M. S. Ramadhan, "Pengaplikasian Teknik Shibori dengan Eksplorasi Motif dan Tekstur Taktil pada Produk Fashion," Jurnal ATRAT, vol. 6, no. 3, pp. 242-253, 2018.

[6] M. Southan, Shibori: Design and Techniques, Wellwood: Search Press Ltd, 2008.

[7] B. Lawson, Bagaimana Cara Berpikir Desainer, Yogyakarta: Jalasutra, 2012.

[8] B. Irawan and P. Tamara, Dasar-Dasar Desain: Untuk Arsitektur, InteriorArsitektur, Seni Rupa, Desain Produk Industri dan Desain Komunikasi Visual, Jakarta: Griya Kreasi, 2013.

[9] S. Sanyoto, Nirmana: Elemen-Elemen Seni dan Desain, Yogyakarta: Jalasutra, 2009.

[10] A. Rahayu, "Peran Warna dalam Arsitektur sebagai Salah Satu Kebutuhan Manusia," Universitas Indonesia, Jakarta, 2012. 